\title{
運動の高次神経機能障害の評価
}

\section{Evaluation of Motor Impairment Due to Higher Brain Dysfunction}

\section{網本 和}

\section{KAZU AMIMOTO}

Department of Rehabilitation Medicine, St. Marianna University School of Medicine Hospital:

2-16-1 Sugao, Miyamae-ku, Kawasaki 216, Japan. TEL +81 44-977-8111

Rigakuryoho Kagaku 12(3): 149-154, 1997. Received Jun. 20, 1997.

ABSTRACT: Clinical symptoms of motor impairment resulting from higher brain dysfunction are reviewed here by classifying them into apraxia and other impairments than apraxia. Then, idetional apraxia and Pusher sign are further described. Analysis of error responses is of importance in the evaluation of idetional apraxia, and description of motor pattern as well as the analysis of the severity is essential in the evaluation of Pusher sign.

Key words: higher brain dysfunction, apraxia, Pusher sign

要旨:運動の高次神経機能障害の諸症状について, 失行症と失行症以外の行為の障害に分類して概説した。こ れらのうち特に, 観念失行と Pusher 現象を取り上げ詳述した。観念失行の評価では誤反応の性質を分析する こと,およびPusher 現象の評価では重症度分析に加え動作パターンを記述することが重要である。 キーワード: 高次神経機能障害, 失行症, Pusher 現象

聖マリアンナ医科大学病院リハビリテーション部：川崎市宮前区菅生 2-16-1（テ 216）TEL 044-977-8111

受付日 1997 年6月20日 


\section{I.はじめに}

周知のように神経心理学の研究史を顧みれば, 早くか ら言語症状である失語にその重点がおかれて, またその 対応としての言語治療が発展してきた。それゆえ理学療 法士が直接高次神経機能障害にかかわることは皆無では ないものの, 多数派ではなかった。しかし高次神経機能 障害への対応については理学療法学の領域でも関心を集 めつつあり，これに関する報告も最近されるようになっ た2)。

ところがこれまでに理学療法学の領域で扱われた高次 神経機能障害は概ね『半側無視』に関連したものが殆ど であり,『運動の高次神経機能障害』に関わる研究は, 理 学療法学の最も得意とする分野であるかに見えるにも関 わらず，事実上成されていない。その意味で本稿では， 『運動の高次神経機能障害』をどのようにとらえ, 理解す べきか, そして臨床評価にいかに結実させるかを目標と している。そこでまず『運動の高次神経機能障害」の範 囲, 定義を述べ, つづいてとりわけ重要であると考えら れる『観念失行』，『Pusher 現象』について言及する。

\section{II. 運動の高次神経機能障害}

\section{$<$ 失行症 $>$}

(1) 観念運動失行

日常物品を使用しない意図的な慣習動作や物品を使う まねをさせた時に困難となるもので, これは言語命令に 限らず模倣でも出現する。観念運動失行の最大の特徴は, 意図的にはできない動作が自然状況下ではスムーズに行 えることである。たとえば舌を出すように指示してもでき ないが, 食事の際に口のまわりを舌でなめることはできる。

(2)観念失行

後述。

(3)肢節運動失行

運動麻瘏, 筋緊張異常, 知覚障害などが見られないに もかかわらず, ボタンをかける, ズボンのポケットに手 を入れるなどの習熟された巧緻運動が拙劣化し, その遂 行に時間がかかる。

(4)着衣失行

衣服の袖に手を通す, ネクタイを結ぶなどのような日 常の着衣動作が困難になるもので, 衣服の上下, 表亭, 左 右などを自分の身体に適合させることができなくなる。

(5)構成失行

物体を組み合わせたり，描画などの構成する行動にお
いて，構成されたものの空間的な形態を完成する事がで きない症状である。その構成対象の形や部分相互の配置 の障害。

(6)脳梁失行

自動的運動や模做は可能であるが，言語命令に対する 左手の反応のみが障害される。すなわち後述する拮抗失 行とは異なり, 脳梁失行での行為障害は検査の場面のみ で認められ，日常生活では認められないとされている。

<失行症以外の行為障害 $>\left(\right.$ 表 1) ${ }^{8)}$

失行症以外の行為障害は以下に述べるような主として 前頭葉損傷例で出現する病的現象が注目されている6)8。

(1)把握反射

手掌に加えられた動的な刺激によって誘発される把握 運動である。これは被検者の手掌に接触させた検者の指 を体幹から末梢の方向へ遠ざけるようにすると指を屈曲 させ, 屈曲した指を更に引っ張ると収縮は一段と強くな り，一度つかんだものは自分では離せなくなる。

(2)本能性把握

手への静的刺激により誘発される緩徐な把握運動であ る。刺激が手の一部分に加えられると, その方向に手を 向けて接触しようとし, ついで手指の屈曲伸展が繰り返

表 1 前頭葉損傷による行為障害

行為の遂行障害 (失行症)

磁性失行 magnet apraxia

観念運動失行

口部失行あるいは頪部顔面失行

運動の開始と維持の障害

運動維持困難

運動開始困難

開眼失行

閉眼失行

歩行失行

運動無視 - 間歇性運動開始困難

行為の抑制障害

左右手の解離性運動抑制障害

本能性把握反応

運動保続

拮抗失行

道具の強迫的使用

行動抑制障害

他人の手徴候（狭義）

利用行動

模做行動

環境依存症候群 
されながら最終的に把握する。症状の強い症例では, 把 握する前に刺激を取り去ろうとすると，その方向にあた かも磁力で引っ張られるように手の探索が起こる。通常 は対側の病巣で出現するが, 右半球損傷で右手に出現す る時があり,これを同側性本能性把握反応という。

(3)道具の強迫的使用

自分の眼の前に置かれた日常物品を意志とは関係なく 使用してしまう。これは右手のみに起こり，左手はこれ を制止しょうとするが止められない。なお関連症状とし て, 道具の強迫的使用が両手を協調させて起こる使用行 為 (Utilization behavior) がある。

(4)拮抗失行

自分の意志に応じた右手の行為に対して左手がそれを 制止あるいは反対の行為をしようとするため目的行為が 完遂できない状態。

(5)他人の手徴候（狭義）

左手が自分の意志とは無関係に, 不随意的な運動を起 こし, 右手がこれを制止しようとする。

(6)歩行失行

歩行動作において下肢を適切に用いることの障害であ り, Gegenhalten, 保続等の存在により, 足底が接地するこ とで運動機能が悪化する。水野 (1983) 7)はこの徴候の臨 床的特徴を表2のように示している。一方，山鳥 (1985) 9) はこの徴候を『失行』と呼ぶのは不適切であるとして, 運 動開始困難ととらえており，本稿もこれにしたがった。

(7) Motor impersistence

一定の運動状態，特に閉眼，提舌を保持する事が困難 な状態。

(8) Pusher 現象

後述。

\section{表 2 歩行失行の臨床的特徴}

1. 立位では, スタンスがやや広く, 前屈姿勢, 足尖は, 屈曲して地面をつかむ様な趾位をとる。

2. 歩行を命ずると, 足が地面に根付いた様でなかなか 踏み出せず，足尖を地面にこすらせながら足を前に 出す.

3.リズムを持った歩行への移行が困難.

4. 上肢の協調した振りがない.

5. これらの歩行障害を説明し得る運動麻㾝, 筋力低下, 運動失調, 痤直, 固縮, 無動, 知覚障害等がない.

6. 把握反射, 緊張性足底反射, 吸引反射, Gegen-halten, 痴呆などの前頭葉徴侯が存在する。

7. 立位で, 躯幹や下肢の筋緊張の六進 (Gegen-halten) が 見られる。

\section{III. 評価方法の基本}

評価においては行為の誤り方とその程度を知る必要が ある。なぜならこれをもとにして治療の出発点を決め, 更に治療効果の再評価に利用するからである。また失行 には失語症を合併していることが多いため, 最初に行為 に対する指示が伝わっているかどうかを確認する必要が ある。したがって失語の程度を検査し，それをふまえた 上で口頭命令，模倣，ジェスチャー，物品使用に対する 検査を行い，どの課題で誤るかによってタイプおよび重 症度を判断する。臨床的にはいずれの要素も含んでいる ことが多く，はっきりとは分類できない。したがって「課 題ができた，できない」ではなく，どのように反応した のかを詳細に分析する。

さらに机上の検査で行為障害が顕著なのに病棟では食 事動作が遂行可能など, 検查場面と日常生活場面での解 離が見られることが多い。したがって検査結果だけでは なく, 病棟での生活などをふまえて総合的に評価してい かなければならない。本邦では標準高次動作性検査が広 く用いられている(表3)。

\section{IV. 観念失行}

単一あるいは複数の日常物品の使用障害であり, 対象 物品の認知や目的行為を了解しているのにもかかわら ず，実際に物品を使用すると誤ってしまう。たとえば煙 草に火をつけるまねや，その動作を口頭で説明できても， 物品を持たせると火のついていないマッチ軸を煙草に近 づけたり，マッチをくわえたりする(錯行為) など, 物品 の概念や順序を間違えてしまう症状である。

観念失行の評価について，博野ら (1994） ${ }^{5)}$ はどの物品 に対して，どのような状況でその障害が認められるかを 把握する事が重要であると指摘している。すなわち，櫛 が使えない場合と，箸が使用できないときではADLに与 える影響は異なっているためである。失行症の動作分析

表 3 DeRenzi $の$ 誤反応分類

\begin{tabular}{ll}
\hline 1. 当惑 & perplexity \\
2. 拙劣 & clumsiness \\
3. 省略 & omission \\
4. 誤配置 & mislocation \\
5. 誤用 & misuse \\
6. 誤順序 & sequence errors
\end{tabular}


に関するその誤りの分類として, DeRenzi ら (1988) ${ }^{4) の ~}$ カテゴリー分類（表4）が有用である。これらのうち特に sequence errorsは杖歩行を指導するときに，その順序を間 違えてしまうことなどで観察される。

\section{Pusher現象}

Davies（1985） 3)は体軸のずれという観点を中心に 『Pusher 症候群』を論じ，この症候を示す片麻瘏例はいわ ゆる健側の上下肢によって杖などを押してしまい, 正中 軸をこえて麻瘏側方向へ転倒することを指摘した。この 『Pusher 症候群』に関して我々はとくに『基本動作におけ る押す現象』をPusher現象とよび, 独自に評価用紙を作 成した (表 5)。

ここに示されているように坐位, 立位, 歩行のみを取 り上げているのでその他の動作, 例えば移乗動作などを 評価して追加する必要があるが全体的なPusher現象を把 握するには有用であると考えられる。分析の結果この現 象が Motor impersistence, 病態失認, 痴呆などの脳の全般 的障害と連関する事, さらに日常生活の自立度, 半側無 視との関連について報告した1)。

この評価で示されるものはPusher現象の重症度という 観点が主眼であるが, 個々の症例では動作の反応様式, いわゆるパターンを記述する事も重要である。特に負荷 を与えたとき, 上下肢の支持方法を変更したときの反応 などが臨床的には有用である。例えば坐位保持のとき, 麻痺側が下になるように坐面を傾斜させると, Pusher 現 象を示さない症例では立ち直るような反応を示すことが 多いが, Pusher 現象を示す症例では保持できずに転倒す る。ところがこの時上肢の支持方向を側方から前上方に すると(縦の手すりなどを用いて) 姿勢の保持が可能に なることがある。すなわち Pusher 現象はどのような状況 で出現するのか, その持続性についてはどうか, などを 分析的に記述することが重要である。

\section{VI. 今後の課題}

以上運動の高次神経機能障害について, この範疇に含 まれる症状について概観してみると, 例えば筋力, 可動 域等のようにすでにその評価方法が確立した領域とは異 なっていることが明らかであり, 多くの課題が残されて いる。まずどのような徵候が運動の高次神経機能障害な のかを知る必要があり, 単なる麻痺や感覚の障害では説 明できない症状があればそれを高次神経機能の問題に帰 することができるかどうかについて考えてみるべきであ
表 4 標準高次動作性検査の構成

\begin{tabular}{|c|c|}
\hline 大 項 目 & 小 項 目 \\
\hline 1. 餞面動作 & $\begin{array}{l}\text { l. 舌を出す } \\
\text { 2. 舌打ち } \\
\text { 3. 咳 }\end{array}$ \\
\hline そ. 物品を使う顔面動作 & 火を吹き消す \\
\hline 3. 上肢 (片手) 慣習的動作 & $\begin{array}{llr}\text { l. } & \text { 軍隊の敬礼 } & \text { (右) } \\
\text { 2. おいでおいで } & \text { (右) } \\
\text { 3. じゃんけんのチョキ(右) } \\
\text { 4. } \text { 軍隊の敬礼 } & \text { (左) } \\
\text { 5. おいでおいで } & \text { (左) } \\
\text { 6. じゃんけんのチョキ(左) }\end{array}$ \\
\hline 4. 上肢(片手)手指構成模做 & $\begin{array}{l}\text { l. } \text { ルリアのあご手 } \\
\text { 2. I III IV 指輪 (ring) } \\
\text { 3. I V 指輪 (ring) (移送) }\end{array}$ \\
\hline 5. 上肢(両手)客佉のない動作 & $\begin{array}{l}\text { l. 8の字 } \\
\text { 2. 蝶 } \\
\text { 3. グーパー交互テスト }\end{array}$ \\
\hline 6. 上肢(片手)連统的動作 & ルリアの屈曲指签と伸展こぶし \\
\hline 7. 上肢・着衣動作 & 着る \\
\hline $\begin{array}{l}\text { 8. 上肢・物品在使う動作 } \\
\text { 1 上肢・物品を使う動作 } \\
\text { (物品なし) }\end{array}$ & 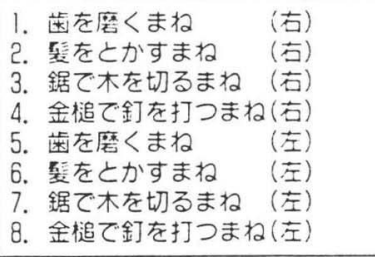 \\
\hline $\begin{array}{r}\text { 巳 上肢・物㣽を使う動作 } \\
(\text { 物品あり) }\end{array}$ & 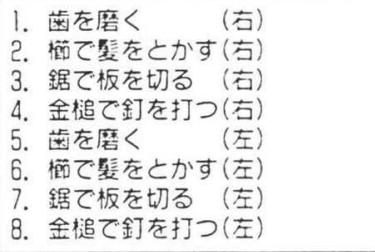 \\
\hline 9. 上肢. 系列的動作 & $\begin{array}{l}\text { 1. お䒩を入れて飲む } \\
\text { 2. ローソクに火をつる }\end{array}$ \\
\hline 10. 下肢・物品を使う動作 & $\begin{array}{l}\text { 1. ボールをける(䓃) } \\
\text { 2. ボールをける(左) }\end{array}$ \\
\hline 11. 上肢・描画(自発) & $\begin{array}{l}\text { 1. 三角をかく } \\
\text { 2. 日の丸の旗をかく }\end{array}$ \\
\hline 12. 上肢·描画(模做) & 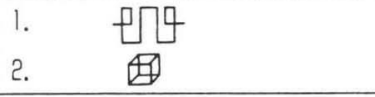 \\
\hline 13. 積木テスト & $\nabla$ \\
\hline
\end{tabular}

スクリーニング・テスト用項目

\begin{tabular}{|l|l|}
\hline I. 顔面動作 & $\begin{array}{l}\text { l. 舌を出す } \\
\text { 2. 舌打方 } \\
\text { 3. 咳 }\end{array}$ \\
\hline 2. 上肢(片手)手指構成模倣 & $\begin{array}{l}\text { 1. ルリアのあご手 } \\
\text { 2. I III N指輪 (ring) } \\
\text { 3. I V 指輪 (ring) (移送) }\end{array}$ \\
\hline 3. 上肢・描画(模做) & 1. \\
\hline
\end{tabular}

標準高次動作性検㚗では, 正誤のみならず䛈反応を分類に従い記載でき る. 


$$
\text { 《pusher》評価チャート }
$$

座位

両足接踵の腰かけ・背もたれなしの平面座面で,

座位で上肢（健側）をついて座る。(starting position)

り・すぐに(60 秒以内) 右手で押し始め正中軸を越え体幹が傾き左後方へくすれれ

2・てしまう，上肢をはずすと座位保持ができない。これがほとんど常に起こる， | 分程度以上は保持できるか, あるいは 5 回に、〜 2 回程度たまに押してし

1:まう.

上肢をはずしても 5 分程度なら座位保持できる

自立，押すことはない。

0：10 分以上背もたれ・上肢の支持なしで座位保持できる. 〔注：これを「自立」とみなす〕

立位

平行棒内立位で評価（LLB なとをを装着してもよい）いっん肩幅程度に両足を

ひらいて立ち、平行棒をもたせる。

すぐに(30 秒以内) 右手で押し始め, 左側の骨盤帯が左側の平行棒についてし

2: まう。あるいは左後方へ倒れる。「右側の bar に腰をつける」ように指示して もかえって左側へ移動する。

時間が経つと (30 秒以内) 押し始めて左側へいってしまう.

1：しかし「右側の bar につける」ように言うと可能である.

右側の bar に寄りかかって। 分以上保持してもよい.

右手で bar をもち、かつ寄りかからず

0! また左側へ偏位せす।分以上保持できる

〔注：この場合でも pusher がないというだけで、「自立」ではない】

歩行

4 点杖などの適当な杖をもち $10 \mathrm{~m}$ 歩行(介助でもよい)を行う

(LLBなどの装着可)

杖をついての静止立位はなんとか保持できるが，歩き始めようとすると．か

2・えって右下肢・上肢で押し始め、上部体幹が正中軸を越え倒れる。倒れないよ

2・う介助すると.かえって押すカを強める。

〔注：杖を使用するよりも，かかえこむような介助歩行のほうが容易である〕

步行スピード；10 m 介助歩行で3分以上かかる.

杖を体側横につくと押してしまい, 正中軸を越えるが, 前について歩行すると

1：容易になる，肩・骨盤など।カ所サホートするたけけで歩行可能である。しかし サポートしている部は押している。

歩行スピート；10m (1 分〜3 分)

患側を振り出すことに比較して健側の swing が容易である

0!サポートが必要なときでも、艺の部分を押すことはない。

〔注：この段階でもいわゆる「自立」ではない〕

歩行スピード: $10 \mathrm{~m}$ | 分以内

総合得点

くコメント> 
ろう。次に理学療法の立場から動作学的に分析し, 量的 質的に記述し，一定の評価基準に構成して行くことが求 められる。このような試みは未だに端緒にもついていな いといわざるを得ない。諸賢の挑戦が期待されている。

\section{文 献}

1) 網本 和·他: 左半側無視例に抢ける『Pusher 現象」の重症 度分析. 理学療法学, 21:29-33, 1994.

2) 網本 和: 高次神経機能障害に対する治療的接近. PTジャー ナル, 30: 606-613, 1996.
3) Davies PM: Steps to follow, Springer-Verlag, 1985.（冨田昌夫 訳：ステップス・トウ・フォロー. シュプリンガー・フェア ラーク, 東京, pp285-304, 1987)

4) DeRenzi E, Lucchelli F :Ideational apraxia. BRAIN 111;1173$1185,1988$.

5）博野信次·他: 観念失行を理解するために. OT ジャーナル, 28: 588-593, 1994.

6) 平山恵造: 前頭葉病変と行為障害. 神経心理学, 9: 2-12, 1993.

7) 水野美邦：歩行失行. 総合リ八, 11: 609-613, 1983.

8) 森 悦朗 - 他: 前頭葉と行為障害. 神経進歩, 37: 127-138, 1993.

9) 山鳥 重: 神経心理学入門. 医学書院, 1985. 